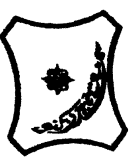

Bayero Journal of Pure and Applied Sciences, 10(1): 560 - 564

ISSN $2006-6996$

\title{
ASSESSMENT OF THE LEVELS OF HEAVY METALS IN THREE WETLANDS OF NORTHERN NIGERIAN
}

\author{
${ }^{1}$ Yusuf, S. ${ }^{2}$ Audu, A. A. and ${ }^{3}$ Waziri, M. K. \\ 1, 2Department of Pure and Industrial Chemistry, Bayero University, P. M. B. 3011, Kano, Nigeria \\ ${ }^{3}$ Department of Chemistry, Federal University, Gashua. \\ Email: sayzay37@yahoo.com; aaaudu.chm@buk.edu.ng
}

ABSTRACT

The levels of some heavy metals ( $\mathrm{Cu}, \mathrm{Pb}, \mathrm{Zn}, \mathrm{Cd}, \mathrm{Cr}$, and $\mathrm{Ni}$ ) were seasonally determined in water samples from 35 sites which include Jebba, Baturiya, Lokoja, Matara-Uku and Nguru wetlands. The water samples were digested with concentrated trioxonitrate (V) acid at $85^{\circ} \mathrm{C}$ for 2 hours on a hot plate and the metal levels were measured using atomic absorption spectrophotometer (Agilent, Varian AA240FS). The following range of values were obtained for the heavy metals; $\mathrm{Cu}(0.001 \pm 0.0003$ to $0.152 \pm 0.0001 \mathrm{mg} / \mathrm{l}), \mathrm{Pb}(0.236 \pm 0.0001$ to $1.06 \pm 0.0002 \mathrm{mg} / \mathrm{l}), C d(0.001 \pm 0.0004$ to $0.014 \pm 0.0017 \mathrm{mg} / \mathrm{l}), \mathrm{Cr}(0.009 \pm 0.0011$ to $0.075 \pm 0.0004 \mathrm{mg} / \mathrm{l}), \mathrm{Zn}(0.001 \pm 0.0003$ to $0.154 \pm 0.0012 \mathrm{mg} / \mathrm{l})$ and $\mathrm{Ni}(0.014 \pm 0.0002$ to $0.276 \pm 0.0007 \mathrm{mg} / \mathrm{l})$. Pearson correlation coefficient, analysis of variance and Tukey's test were used to assess the data and it was observed that lead has the highest mean concentration out of the six metals measured. When the metals levels were graduated, they were found to be in the order of $\mathrm{Pb}>\mathrm{Cu}>\mathrm{Ni}>\mathrm{Cr}>\mathrm{Zn}>\mathrm{Cd}$ in the wet season but the order changed drastically in the dry season to $\mathrm{Pb}>\mathrm{Zn}>\mathrm{Cu}>\mathrm{Cr}>\mathrm{Cd}>\mathrm{Ni}$. The $\mathrm{Pb}, \mathrm{Cr} \mathrm{Ni}$ and $\mathrm{Cd}$ concentrations in all the sites of the wetland were higher than the WHO and NAFDAC guidelines, indicating that they wetlands water samples are unsafe for human consumption, thus relying on these wetlands as sources of food would have serious public health implications.

Keywords: Heavy metals, wetlands, water samples,

\section{INTRODUCTION}

The contamination of the environment by heavy metal is of great concern globally because metals do not break down into less harmful substances and present a number of environmental risks ( $\mathrm{Li}$ et al. 2004). Heavy metals like Copper ( $\mathrm{Cu}$ ) and Zinc ( $\mathrm{Zn})$ are essential metals for plant growth and productivity. However, plants may accumulate heavy metals present in soil water, like Cadmium (Cd), Nickel (Ni), Chromium ( $\mathrm{Cr}$ ) and Lead $(\mathrm{Pb})$ which are not essential for plant growth and this may pose threat to environment (Mitsios, et al. 2005).

Wetlands are important functional interface zone between the freshwater ecosystem and terrestrial ecosystem, which can provide vital ecosystem services, such as fisheries resources and habitant, food for migratory and resident animals, aesthetic landscape, and recreational opportunities for human populations (Wang and Feng, 1997). Wetlands are low areas where heavy metals are more easily accumulated due to changes of natural environment and influences of anthropogenic activities (Mays and Edwards, 2001). Among the anthropogenic sources of heavy metals are industrial and domestic waste discharges as well as trafficrelated emissions (Karvelas et al. 2003). Wastewater treatment plants significantly control the discharge of heavy metals into water bodies, but in the West African region where these treatment plants operated below standard, untreated industrial and urban sewage are frequently discharged into water canals and find their way to wetlands (Affian et al. 2009)

Since wetlands are important sources of food and water for human beings, the heavy metals levels in the wetlands can eventually put human health at risk. This may occur as a result of the use of water by people in these areas for their daily activities, in industrial processes and in agriculture as well as the gradual build up of these metals in the food chain. For these reasons, researches on the distribution of heavy metal pollutants in wetlands are of immense importance. Therefore, the aim of this study is to determine the concentration of heavy metals in wetlands water samples and assess their distribution and seasonal variation among the wetlands. 


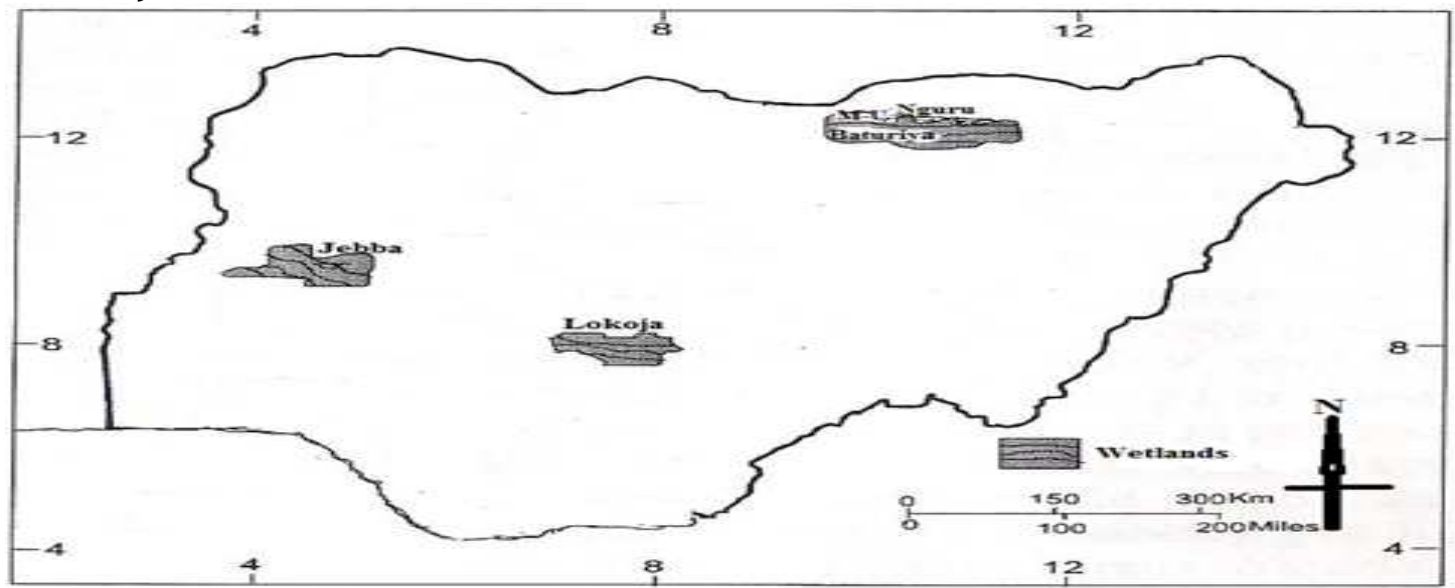

Figure 1: Nigeria Map Showing the Wetlands

\section{MATERIALS AND METHODS}

All chemicals that were used are analytical reagent grade and solutions prepared using deionised water.

\section{Sampling and sample treatment}

Water samples from the wetlands were collected in $1000 \mathrm{~cm}^{3}$ white, low-density polyethylene bottles from 35 sites spread across five sampling locations at $200 \mathrm{~m}$ apart. The water samples were collected by immersing the sample containers nozzle down 0.5 meter and slowly allowing them to fill. The water samples were acidified using $3.0 \mathrm{~cm}^{3}$ of 1:1 trioxonitrate (V) acid. This reduces precipitation and sorption losses to the container walls. Samplings were carried out during the early part of the dry and the wet season. All the samples were appropriately labelled, stored in a large plastic container with ice blocks and transported to the laboratory. The water samples were then filtered using $0.7 \mu \mathrm{m} \mathrm{GF/F}$ glass fiber filter and then stored in a refrigerator at $4{ }^{\circ} \mathrm{C}$.

Sample digestion

$500 \mathrm{~cm}^{3}$ of the filtered water sample in a 1000 $\mathrm{cm}^{3}$ was placed on a hot plate and evaporated to about $50 \mathrm{~cm}^{3}$. It was allowed to cool and transferred into a $250 \mathrm{~cm}^{3}$ beaker. $5 \mathrm{~cm}^{3}$ of concentrated $\mathrm{HNO}_{3}$ was added and the resulting solution was heated at $85^{\circ} \mathrm{C}$ until a clear solution was obtained. The digested sample was allowed to cool, then transferred into a 100 $\mathrm{cm}^{3}$ volumetric flask and made up to mark with deionised water. This solution was then used for the heavy metals analysis using Atomic Absorption Spectrophotometer (AAS).

\section{Preparation of Standard Solutions}

Preparation of $1000 \mathrm{mg} / \mathrm{l}$ Copper Stock Solution

$1.0000 \mathrm{~g}$ of copper metal was dissolved in 50 $\mathrm{cm}^{3}$ of $5 \mathrm{M}$ trioxonitrate $(\mathrm{V})$ acid solution in a $1000 \mathrm{~cm}^{3}$ volumetric flask and diluted to mark with deionised water.

Preparation of $1000 \mathrm{mg} / \mathrm{l}$ Lead Stock Solution $1.5985 \mathrm{~g}$ of $\mathrm{Pb}\left(\mathrm{NO}_{3}\right)_{2}$ was dissolved in approximately $100 \mathrm{~cm}^{3}$ of water in a $1 \mathrm{~L}$ volumetric flask and made up to $1 \mathrm{~L}$ with deionised water.

Preparation of $1000 \mathrm{mg} / \mathrm{l}$ Cd Stock Solution $1.0000 \mathrm{~g}$ of cadmium metal was dissolved in 20 $\mathrm{cm}^{3}$ of $6.0 \mathrm{M} \mathrm{HNO}_{3}$ in a $1000 \mathrm{~cm}^{3}$ volumetric flask and made up to $1 \mathrm{~L}$ with deionised water. Preparation of $1000 \mathrm{mg} / \mathrm{l} \mathrm{Cr}$ Stock Solution $2.8290 \mathrm{~g}$ of $\mathrm{K}_{2} \mathrm{Cr}_{7} \mathrm{O}_{7}$ was dissolved in $100 \mathrm{~cm}^{3}$ of 6.0 $\mathrm{M} \mathrm{HNO}_{3}$ in a $1000 \mathrm{~cm}^{3}$ volumetric flask and made up to mark with deionised water

Preparation of $1000 \mathrm{mg} / \mathrm{l}$ Zn Stock Solution $1.0000 \mathrm{~g}$ of zinc metal was dissolved in $20 \mathrm{~cm}^{3}$ of $6.0 \mathrm{M} \mathrm{HNO}_{3}$ in a $10000 \mathrm{~cm} 3$ volumetric flask and the volume made up to $1 \mathrm{~L}$ with deionised water.

Preparation of $1000 \mathrm{mg} / \mathrm{l}$ Ni Stock Solution $1.0000 \mathrm{~g}$ of $\mathrm{Ni}$ metal was dissolved in $20 \mathrm{~cm}^{3}$ of 6.0 $\mathrm{M} \mathrm{HNO}_{3}$ in a $10000 \mathrm{~cm} 3$ volumetric flask and the volume made up to $1 \mathrm{~L}$ with deionised water.

Preparation of $100 \mathrm{mg} / \mathrm{l}$ Standard Solution $100 \mathrm{~cm}^{3}$ of the $1000 \mathrm{mg} / \mathrm{l}$ stock was transferred into $1000 \mathrm{~cm}^{3}$ volumetric flask and made up to mark with deionised water to make $100 \mathrm{mg} / \mathrm{l}$ solution. The working standards were prepared by pipetting $1.0,2.0,4.0,6.0,8.0,10.0$ and $12.0 \mathrm{~cm}^{3}$ of the $100 \mathrm{~cm} 3$ solution into labelled $100 \mathrm{~cm} 3$ volumetric flasks and the volume made up to mark with deionised water to make solutions containing 1.0, 2.0, 4.0, 6.0, 8.0, 10.0 and $12.0 \mathrm{mg} / \mathrm{l}$ of the metals. 
$6 \mathrm{M}$ Trioxonitrate $(\mathrm{V})$ acid

$386 \mathrm{~cm}^{3}$ of concentrated $\mathrm{HNO}_{3}$ (specific gravity; $1.42,69 \% \mathrm{w} / \mathrm{v}$ ) was measured and added to 500 $\mathrm{cm}^{3}$ deionised water in a $1000 \mathrm{~cm}^{3}$ volumetric flask. The resulting solution was made up to mark with deionised water.

\section{Metal Determination}

The absorbance values of $\mathrm{Pb}, \mathrm{Cu}, \mathrm{Cd}, \mathrm{Cr}, \mathrm{Zn}$ and $\mathrm{Ni}$ in the water samples were taken using Atomic Absorption Spectrophotometer at their individual absorption lines. Instrumental calibration was carried out prior to metal determinations by taking the absorbance values of the standard solutions prepared for the various metals. Calibration curves for the different metals were plotted using the results obtained. The water samples were aspirated into the spectrophotometer and the absorbance reading recorded. The same procedure was used for the blank and standard solutions. The concentrations of metals were extrapolated from the calibration curves.

Data Analysis

All analyses were performed in triplicates and the results were expressed as means of $\pm S D$.
The difference in metals concentrations among the different sites were treated by Pearson correlation, one-way analysis of variance method, (ANOVA) and Tukey's test was used to determine pair wise differences among locations. In analysis where $\mathrm{P}<0.05$, the comparisons were considered statistically significant. All statistical calculations were performed with SPSS 20.0 for windows.

\section{RESULTS AND DISCUSSION}

Copper $(\mathrm{Cu})$ : The $\mathrm{Cu}$ levels (Figures 2 \& 3 ) in all the samples were below the permissible limit of $2 \mathrm{mg} / \mathrm{l}$ defined by WHO (2011). When the Tukey's test was applied, it was observed that the difference between the mean concentrations of copper, in sites $J \&$ \& , BR \& $N, M \& N$ and LA \& $N$ were all greater than the Least Significant Difference, LSD, (0.0189), indicating that the mean concentration of $\mathrm{Cu}$ in site $\mathrm{N}$, is significantly lower than those recorded in all the other sites during the dry season. Similarly, the difference between the mean of $\mathrm{Cu}$ in site LA and that of J, BR, M and $\mathrm{N}$ are significant as they exceeded the LSD value.

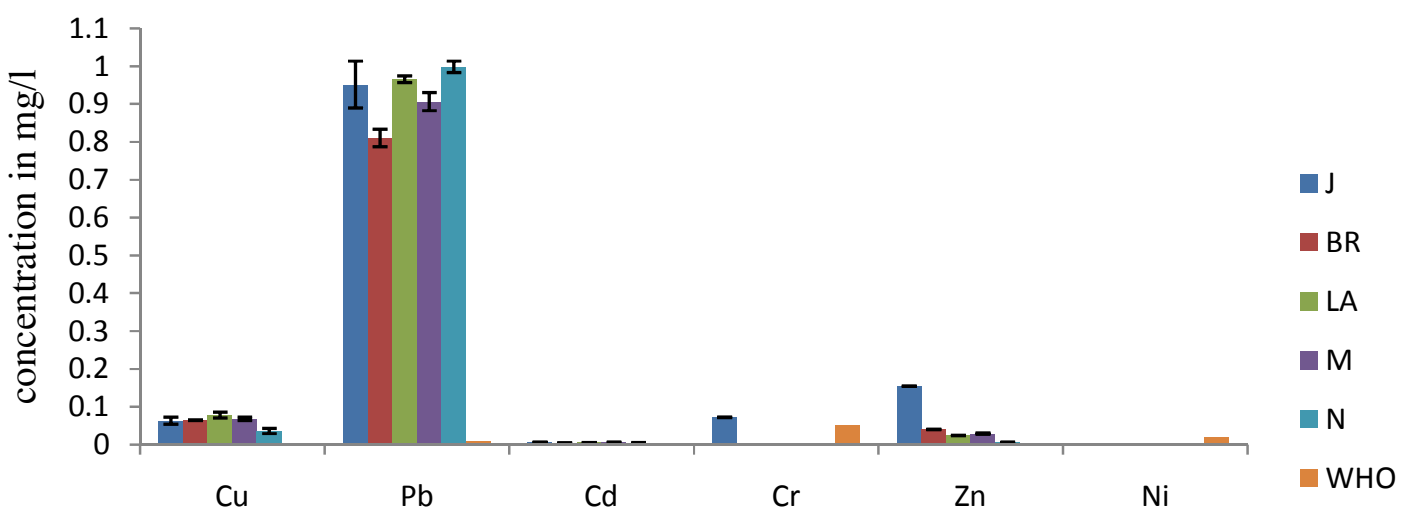

Figure 2: Heavy metals Level in Water from Wetlands during the Dry Season

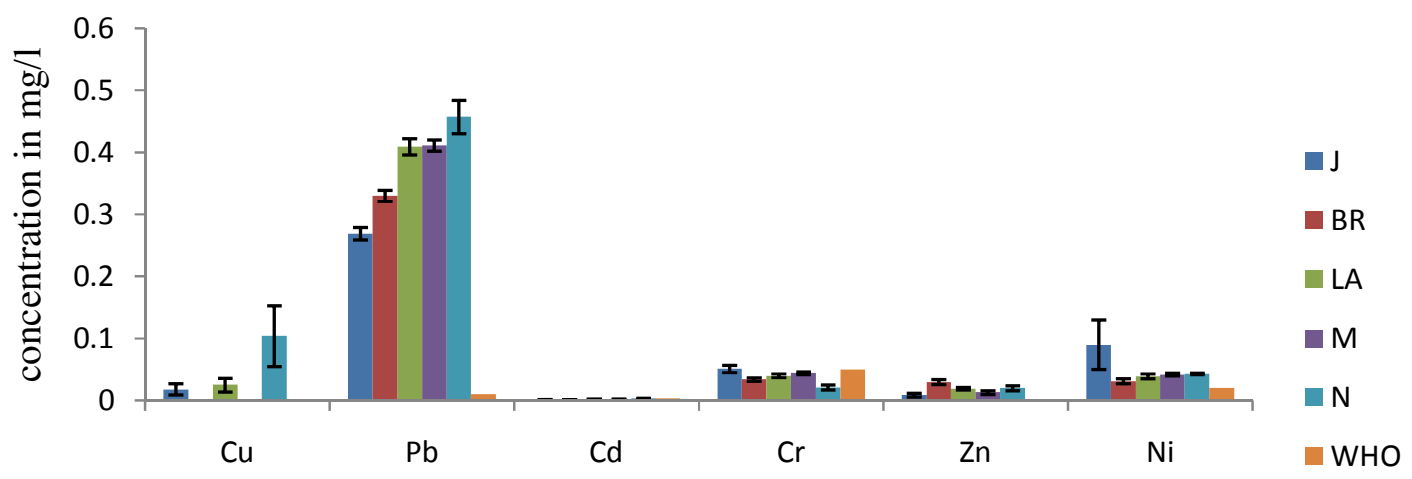

Figure 3: Heavy metals Level in Water from Wetlands during the Wet Season 
Lead $(\mathrm{Pb})$ : The $\mathrm{Pb}$ content (Figure 2 \& 3 ) of all the water samples were higher than the permissible limit of $0.01 \mathrm{mg} / \mathrm{l}$ set by WHO (2011). The LSD value for $\mathrm{Pb}$ in the dry season is 0.0908 . It was observed that the difference between the mean concentrations of $\mathrm{Pb}$ in sites $M$ \& $B R, J \& B R, L A$ \& $B R$ and $N$ \& $B R$ were all above the LSD value which indicated that the level of $\mathrm{Pb}$ in site $\mathrm{BR}$ is significantly lower than the level of $\mathrm{Pb}$ in sites $\mathrm{M}, \mathrm{J}, \mathrm{LA}$ and $\mathrm{N}$. Similarly, the levels of $\mathrm{Pb}$ in sites $\mathrm{N} \& \mathrm{M}$ show a significant difference at $\mathrm{p}<0.05$. In addition, a significant variation was observed in the levels of $\mathrm{Pb}$ among the various sites during the wet season.

Cadmium (Cd): The $\mathrm{Cd}$ levels of all the water samples collected during the dry season (Figure 2) were greater than the permissible limit of $0.003 \mathrm{mg} / \mathrm{l}$ while those obtained during the wet season (Figure 3) were below the limit set by WHO (2011). However, the difference between the mean concentration of $C d$ in $M$ \& $J$, LA \& J, and $\mathrm{N} \& \mathrm{~J}$ which are 0.000857, 0.00215 and 0.00272 are greater than the LSD, this indicates that the mean concentration of $\mathrm{Cd}$ in site $\mathrm{J}$ is significantly lower than those of sites LA and N. Similarly, there is a significant difference between the mean concentrations of $\mathrm{Cd}$ in $\mathrm{L} \&$ $B R, N \& B R, L A \& M$ and $N \& M$ at $p<0.05$. The concentrations of $\mathrm{Cd}$ show seasonal variations in Jebba (J), Matara-Uku (M) and Lokoja (LA) wetlands where $\mathrm{Cd}$ concentrations in the dry season is greater than those obtained in the wet season at $p<0.05$.

Chromium ( $\mathrm{Cr}$ ): The $\mathrm{Cr}$ content of water samples collected from Jebba during the wet and the dry seasons (Figure $2 \& 3$ ) were greater than the permissible limit of $0.05 \mathrm{mg} / \mathrm{l}$ while those collected from Baturiya (BR), Lokoja (LA), Matara-Uku (M) and Nguru (N) were below the limit set by, WHO (2011). The LSD value for $\mathrm{Cr}$ in the wet season is 0.0109 . when this is compared with the differences obtained between the mean concentration of $\mathrm{Cr}$ in the various sites, it was observed that there is a significant difference between the mean concentration of $\mathrm{Cr}$ in $\mathrm{BR} \& \mathrm{~N}, \mathrm{LA} \& \mathrm{~N}, M \& \mathrm{~N}, J$ \& $N$ and $N$ \& $B R$ at $p<0.05$.

Zinc (Zn): The $\mathrm{Zn}$ levels (Figure $2 \& 3$ ) of all the samples were below the permissible limit of 3 $\mathrm{mg} / \mathrm{l}$ set by WHO (2011). However, there is a significant difference between the mean concentrations of $Z n$ in LA \& J, N\& J, BR \& J, $B R \& M, B R \& L A$ and $B R \& N$ as the difference between their mean concentrations exceed the $L S D$ value. The low concentration of $\mathrm{Zn}$ in the water samples is due to its restricted mobility from the natural sources

Nickel (Ni): The Ni levels (Figure 3 ) of all the water samples collected during the wet season were greater than the permissible limit of 0.02 $\mathrm{mg} / \mathrm{l}$ set by WHO (2011). But Ni was not detected during the dry season (Figure 2).

The mean values of heavy metal concentrations can be arranged in the order $\mathrm{Pb}>\mathrm{Zn}>\mathrm{Cu}>\mathrm{Cr}$ $>\mathrm{Cd}>\mathrm{Ni}$ during the dry season but drastically changed in the wet season as $\mathrm{Pb}>\mathrm{Cu}>\mathrm{Ni}>\mathrm{Cr}$ $>\mathrm{Zn}>\mathrm{Cd}$. The levels of $\mathrm{Pb}, \mathrm{Ni}, \mathrm{Cr}$ and $\mathrm{Cd}$ were higher in these wetlands, whereas those of $\mathrm{Zn}$ and $\mathrm{Cu}$ were low. Since these wetlands are used for fishing and irrigation, comparison of reported results of this study with irrigation water, drinking water and aquatic life guidelines revealed that the concentrations of heavy metals recorded were below the guideline set for irrigation (FAO, 1994) and above the guidelines set for drinking water and aquatic life. However, the $\mathrm{Pb}$ concentration is 99.8 times greater than the maximum permissible limit set for drinking water and 143 times higher than the guideline set for aquatic life (WHO, 2011; CCME, 2007).

The high levels of $\mathrm{Pb}, \mathrm{Ni}, \mathrm{Cr}$ and $\mathrm{Cd}$ may be due to atmospheric deposition, runoff from farmlands and also the water pump used for getting water from the wetlands are powered by gasoline which may have led to the accumulation of $\mathrm{Pb}$ in the water samples. While comparatively high concentrations of $\mathrm{Cu}$ was observed in sampling site LA (Figure 3), where domestic sewage and wastewater were discharged directly into the wetland. The maximum $\mathrm{Cr}, \mathrm{Cd}$ and $\mathrm{Ni}$ levels occurred at sites $\mathrm{J} 1, \mathrm{M} 1$ and J2. It is noteworthy that there are auto-workshop, dyeing industry and blacksmith industry in the vicinity of sampling sites $M 1$ and BR. Also, the increase in $\mathrm{Ni}$ and $\mathrm{Cr}$ concentrations recorded during the wet season (Figure 3) may be attributed to the liberation of these metals from the sediment to the overlying water under the effect of both high temperature and organic matter decomposition.

Correlation analysis was conducted between heavy metal concentrations in water samples to evaluate if there are similarities in the sources of these heavy metals. Zn shows strong positive correlations with $\mathrm{Cd}$ and $\mathrm{Cr}$ during the dry season, and $\mathrm{Ni}$ during the wet season. Positive correlations were also recorded for $\mathrm{Pb}$ with $\mathrm{Cd}$ and $\mathrm{Cu}$ during the wet season. The possible sources of these heavy metals displaying positive correlations were considered to be similar, which was confirmed by the presence of a relation between levels of these metals. $\mathrm{Pb}, \mathrm{Ni}, \mathrm{Cr}$ and $\mathrm{Cd}$ which showed the highest levels among the analyzed elements, were thought to come from compost manure collected from municipal refuse dump, combustion of gasoline and atmospheric deposition. 
The levels of $\mathrm{Pb}(0.0033-0.0295 \mathrm{mg} / \mathrm{L}), \mathrm{Cr}$ (BDL), Cu (0.00054-0.00092), Zn (BDL) and Cd (BDL) determined in Hengshuihu Wetland of Northern China (Manyin et al., 2009), were lower than the values recorded in this study. Similarly, the values obtained from a wetland in South China for $\mathrm{Pb}(0.0128 \mathrm{mg} / \mathrm{L}), \mathrm{Cr}(0.0085$ $\mathrm{mg} / \mathrm{L}), \mathrm{Cu}(0.0016 \mathrm{mg} / \mathrm{L}), \mathrm{Zn}(0.0089 \mathrm{mg} / \mathrm{L}), \mathrm{Cd}$ $(0.0029 \mathrm{mg} / \mathrm{L})$ and $\mathrm{Ni}(0.0125 \mathrm{mg} / \mathrm{L})$ (Honggan et al., 2010) were also lower than the values we observed in this study. The high values of the metal levels in the present can be as a result of runoff from farmlands were municipal refuse waste are use as manure and atmospheric depositions.

\section{REFERENCES}

Affian, K., Marc, R., Mohamed, M., Digbehi, B., Djagoua, E. V., and Kouamé, F. (2009). Heavy metal and polycyclic aromatic hydrocarbons in Ebrié lagoon sediments. Côte d'lvoire. Environmental Monitoring and Assessment, 159(1-4), 531-541.

CCME, (2007) (Canadian Council of Ministers of the Environment). For the protection of aquatic life. In: Canadian environmental quality guidelines, 1999, Canadian Council of Ministers of the Environment, 1999, Winnipeg.

FAO, (1994). The state of food and agriculture. (FAO Agriculture Series, no. 27) ISBN 92-5-103550-4, Rome (Italy).

Honggang, Z., Baoshan, C., Rong, X. and Hui, Z. (2010). Heavy metals in water, soils and plants in riparian wetlands in the Pearl River Estuary, South China. Procedia Environmental Sciences, 2, 1344-1354.

Karvelas, M., Athanasios, K. and Samara C. (2003). Occurence and fate of heavy metals in the wastewater treatment process. Chemosphere, 53, 1201-1210.

Li, X.D., Lee, S.L., Wong, S.C., Shi, W.Z., Thornton, I., (2004). The study of metal

\section{CONCLUSION}

Lead concentrations were the highest of the six heavy metals studied and followed in the decreasing order as $\mathrm{Pb}<\mathrm{Zn}>\mathrm{Cu}>\mathrm{Cr}>\mathrm{Cd}>\mathrm{Ni}$ during the dry season but changed dramatically as $\mathrm{Pb}>\mathrm{Cu}>\mathrm{Ni}>\mathrm{Cr}>\mathrm{Zn}>\mathrm{Cd}$ in the wet season. The levels of $\mathrm{Pb}, \mathrm{Cr} \mathrm{Ni}$ and $\mathrm{Cd}$ in all the sites in the wetlands, were higher than the WHO and NAFDAC permissible levels indicating that the water samples are unsafe for human consumption. Also, irrigating farmlands with water from these wetlands for food production would have serious public health implications.

contamination in urban soils of Hong Kong using a GIS-based approach. Environmental Pollution 129 (1), 113124.

Manyin, Z., Lijuan, C., Lianxi, S. and Yifei, W. (2009). Distribution and enrichment of heavy metals among sediments, water body and plants in Hengshuihu Wetland of Northern China. ecological engineering 35, 563-569

Mays, P.A. and Edwards, G.S. (2001). Comparison of heavy metal accumulation in a natural wetland and constructed wetlands receiving acid mine drainage. Ecol. Eng. 16, 487-500.

Mitsios, I. K., Golia, E. E. and Tsadilas, C. D. (2005). Heavy Metal Concentrations in Soils and Irrigation Waters in Thessaly Region, Central Greece, Communications in Soil Science and Plant Analysis, 36:(4-6), 487-501

Wang. Q. S. and Feng Z. W. (1997). Ecotone and ecological flows. Acta Ecol Sin 16:52-58.

WHO, (2011). Guidelines for Drinking-water Quality. (fourth ed.), World Health Organisation (WHO). 